\title{
Understanding the effects of climate warming on streamflow and active groundwater storage in an alpine catchment: the upper Lhasa River
}

\author{
Lu Lin ${ }^{1,2}$, Man Gao ${ }^{3}$, Jintao Liu ${ }^{1,2}$, Jiarong Wang ${ }^{1,2}$, Shuhong Wang ${ }^{1,2}$, Xi Chen ${ }^{1,2,3}$, and Hu Liu ${ }^{4}$ \\ ${ }^{1}$ State Key Laboratory of Hydrology-Water Resources and Hydraulic Engineering, Hohai University, \\ Nanjing 210098, People's Republic of China \\ ${ }^{2}$ College of Hydrology and Water Resources, Hohai University, Nanjing 210098, People's Republic of China \\ ${ }^{3}$ Institute of Surface-Earth System Science, Tianjin University, Tianjin 300072, People's Republic of China \\ ${ }^{4}$ Linze Inland River Basin Research Station, Chinese Ecosystem Research Network, Lanzhou 730000, \\ People's Republic of China
}

Correspondence: Jintao Liu (jtliu@hhu.edu.cn)

Received: 11 June 2019 - Discussion started: 17 June 2019

Revised: 28 November 2019 - Accepted: 31 January 2020 - Published: 11 March 2020

\begin{abstract}
Climate warming is changing streamflow regimes and groundwater storage in cold alpine regions. In this study, the Yangbajain headwater catchment in the Lhasa River basin is adopted as the study area to assess streamflow changes and active groundwater storage in response to climate warming. The results show that both annual streamflow and the mean air temperature increase significantly at respective rates of about $12.30 \mathrm{~mm}$ per decade and $0.28^{\circ} \mathrm{C}$ per decade from 1979 to 2013 in the study area. The results of gray relational analysis indicate that the air temperature acts as a primary factor for the increased streamflow. Due to climate warming, the total glacier volume has retreated by over $25 \%$ during the past 50 years, and the areal extent of permafrost has degraded by $15.3 \%$ over the last 20 years. Parallel comparisons with other subbasins in the Lhasa River basin indirectly reveal that the increased streamflow at the Yangbajain Station is mainly fed by the accelerated glacier retreat. Using baseflow recession analysis, we also find that the estimated groundwater storage that is comparable with the GRACE data increases significantly at rates of about $19.32 \mathrm{~mm}$ per decade during the abovementioned period. That is to say, as permafrost thaws, more spaces have been made available to accommodate the increasing meltwater. Finally, a large water imbalance (of more than $5.79 \times 10^{7} \mathrm{~m}^{3} \mathrm{a}^{-1}$ ) between the melt-derived runoff and the actual increase in runoff as well as the groundwater storage is also observed. The re-
\end{abstract}

sults from this study suggest that the impacts of glacial retreat and permafrost degradation show compound behaviors on the storage-discharge mechanism due to climate warming, and that this fundamentally affects the water supply and the mechanisms of streamflow generation and change.

\section{Introduction}

Often referred to as the "Water Tower of Asia", the Tibetan Plateau (TP) is the source area of major rivers in Asia, including the Yellow, Yangtze, Lancang-Mekong, Yarlung Tsangpo-Brahmaputra, $\mathrm{Nu}-\mathrm{Salween}$ and Indus rivers (Cuo et al., 2014). The delayed release of water resources on the TP from glacier melt can augment river runoff during dry periods, meaning that it plays a pivotal role with respect to the water supply for downstream populations, agriculture and industries that rely on these rivers (Viviroli et al., 2007; Pritchard, 2017). However, the TP has experienced a significant warming period over the last 50 years (Kang et al., 2010; Liu and Chen, 2000). Along with rising temperature, major warming-induced changes have occurred over the TP, such as glacier retreat (Yao et al., 2004, 2007) and frozen ground degradation (Wu and Zhang, 2008; Xu et al., 2019). Hence, it is of great importance to elucidate how climate warming 
influences hydrological processes and water resources on the TP.

In cold alpine catchments, glaciers are known as "solid reservoirs" that supply water via streamflow, while frozen ground, especially permafrost, serves as an impermeable barrier to the interaction between surface water and groundwater (Immerzeel et al., 2010; Walvoord and Kurylyk, 2016; Rogger et al., 2017). Since the 1990s, most glaciers across the TP have retreated rapidly due to global warming, and this has caused an increase of more than $5.5 \%$ in river runoff from the plateau (Yao et al., 2007). Meltwater is the key contributor to streamflow increase, especially in headwater catchments with larger glacier coverage (>5\%) (Bibi et al., 2018; $\mathrm{Xu}$ et al., 2019). For example, the total discharge increase of $2.7 \%-22.4 \%$ that is mainly due to increased glacier melt in the upper Brahmaputra (also known as the Yarlung Tsangpo) accounts for more than half of the total discharge increase (Su et al., 2016).

Meanwhile, in a warming climate, numerous studies have suggested that frozen ground on the TP has experienced a noticeable degradation over the past few decades (Cheng and $\mathrm{Wu}, 2007$; $\mathrm{Wu}$ and Zhang, 2008; Zou et al., 2017). Frozen ground degradation can modify surface conditions and change the thawed active layer storage capacity in alpine catchments (Niu et al., 2011). Thawing of frozen ground increases surface water infiltration, supports deeper groundwater flow paths and subsequently enlarges groundwater storage, which is expected to have a profound effect on flow regimes (Kooi et al., 2009; Bense et al., 2012; Walvoord and Striegl, 2007; Woo et al., 2008; Ge et al., 2011; Walvoord and Kurylyk, 2016; Li et al., 2018; Wang et al., 2018). For example, Wang et al. (2018) suggested that ground ice may be a potential water source in continuous permafrost regions of the central TP under global warming. However, in the high mountainous regions of the TP, various terms of water recharge are quite complex, especially at low elevations. In general, permafrost thaw in arctic basins has resulted in a general upward trend of $0.7 \% \mathrm{a}^{-1}-0.9 \% \mathrm{a}^{-1}$ in the groundwater contribution to streamflow, although with no pervasive change in total annual runoff (Walvoord and Striegl, 2007). Similar results have also been found in the central and northern TP (Liu et al., 2011; Niu et al., 2016; Xu et al., 2019). Moreover, a slowdown in baseflow recession was found in the northeastern and central TP (Niu et al., 2011, 2016; Wang et al., 2017), in northeastern China (Duan et al., 2017) and in Arctic rivers (Lyon et al., 2009; Lyon and Destouni, 2010; Walvoord and Kurylyk, 2016).

Generally, in alpine regions, glacier retreat and permafrost thawing that is triggered by climate warming is changing the hydrological processes of storage and discharge. However, direct measurements of changes in permafrost depth or catchment aquifer storage are still difficult to perform at the catchment scale (Xu et al., 2019; Staudinger, 2017; Käser and Hunkeler, 2016). Although their resolution and accuracy are relatively low, GRACE data have always been adopted to as- sess total groundwater storage changes (Green et al., 2011). More importantly, quantitatively characterizing storage properties and sensitivity to climate warming in cold alpine catchments is desired for local water as well as downstream water management (Staudinger, 2017).

$\mathrm{Xu}$ et al. (2019) used a simple ratio of the maximum and minimum runoff to indirectly indicate the change in storage capacity as well as the effects of permafrost on recession processes. An alternative method, namely recession flow analysis, can theoretically be used to derive the active groundwater storage volume to reflect frozen ground degradation in a catchment (Brutsaert and Nieber, 1977; Brutsaert, 2008). For example, groundwater storage changes can be inferred by recession flow analysis, assuming linearized outflow from aquifers into streams (Lin and Yeh, 2017). Due to the complex structures and properties of catchment aquifers, the linear reservoir model may not be sufficient to represent the actual storage dynamics (Wittenberg, 1999; Chapman, 1999; Liu et al., 2016). Hence, Lyon et al. (2009) adopted the nonlinear reservoir to fit baseflow recession curves for the derivation of aquifer attributes, which can be developed to infer aquifer storage. Buttle (2017) used the approach from Kirchner (2009) to estimate the dynamic storage in different basins and found that the storage and release of dynamic storage may mediate the baseflow response to temporal changes. Generally, classical recession flow analysis, which is based on widely available hydrologic data, is still widely used to provide important information on the storage-discharge relationship of a basin (Patnaik et al., 2018).

In this study, the Yangbajain Catchment in the Lhasa River basin is adopted as the study area. The catchment is experiencing glacier retreat and frozen ground degradation in response to climate warming. The main objectives of this study are (1) to assess the changes between surface runoff and baseflow in a warming climate, (2) to quantify active groundwater storage volume using recession flow analysis, and (3) to analyze the impacts of the changes in active groundwater storage on streamflow variation. The paper is structured as follows: Sect. 2 includes the study area, data sources and methods. Sects. 3 and 4 present the changes in streamflow and its components, climate factors and glaciers, as well as a discussion of the changing regimes of streamflow volume and baseflow recession in response to the changes in active groundwater storage and glaciers; finally, the main conclusions are summarized in Sect. 5.

\section{Materials and methods}

\subsection{Study area}

The $2645 \mathrm{~km}^{2}$ Yangbajain Catchment in the western part of the Lhasa River basin (Fig. 1a) lies between the Nyenchen Tanglha mountain range to the northwest and the Yarlung Tsangpo suture to the south. In the center of the catch- 
ment, a wide and flat valley (Fig. 1b) with low-lying terrain and thicker aquifers is in a half-graben fault-depression basin caused by the Damxung-Yangjain Fault (Wu and Zhao, 2006; Yang et al., 2017). As a half-graben system, the northsouth trending Damxung-Yangjain Fault (Fig. 1b) provides access for groundwater flow as manifested by the widespread distribution of hot springs (Jiang et al., 2016). The surface of the valley is blanketed by Holocene colluvium, which is filled with thick alluvial-pluvial sediments from the south, such as gravel, sandy loam and clay. The vegetation in the catchment is characterized by alpine meadow, alpine steppe, marsh, and shrub among others, with the meadow and marsh mainly distributed in the valley and near the river source (Zhang et al., 2010).

Located on the south-central TP, the Yangbajain Catchment is a glacier-fed headwater catchment with significant frozen ground coverage (Fig. 1b, c). A majority of glaciers were found along the Nyenchen Tanglha mountain range (Fig. 1b). Glaciers cover over $10 \%$ of the whole catchment, making it the most glacierized subbasin in the Lhasa River basin. According to the First Chinese Glacier Inventory (Mi et al., 2002), the total glacier area was about $316.31 \mathrm{~km}^{2}$ in 1960. The ablation period of the glaciers ranges from June to September with the glacier termini at about $5200 \mathrm{~m}$ (Liu et al., 2011). According to the new map of the permafrost distribution on the TP (Zou et al., 2017), the valley is underlain by seasonally frozen ground (Fig. 1c). It is estimated that seasonally frozen ground and permafrost account for about $64 \%$ and $36 \%$ of the total catchment area, respectively (Zou et al., 2017). The lower limit of alpine permafrost is around $4800 \mathrm{~m}$, and the thickness of permafrost varies from 5 to $100 \mathrm{~m}$ (Zhou et al., 2000).

The Yangbajain Catchment is characterized by a semiarid temperate monsoon climate. The areal average annual air temperature of the catchment is approximately $-2.3^{\circ} \mathrm{C}$, and it varies from $-8.6^{\circ} \mathrm{C}$ in January to $3.1^{\circ} \mathrm{C}$ in July (Fig. 2). The average annual precipitation at the Yangbajain Station is about $427 \mathrm{~mm}$. The catchment experiences a summer (JuneAugust) monsoon that provides $73 \%$ of the annual precipitation, while the rest of the year is dry with only $1 \%$ of the annual precipitation occurring in winter (December-February; Fig. 2).

The average annual streamflow at the Yangbajain Station is $277.7 \mathrm{~mm}$, and the intra-annual distribution of streamflow is uneven (Fig. 2). In summer, streamflow is mainly recharged by monsoonal rainfall and meltwater, and the volume of summer runoff accounts for approximately $63 \%$ of the annual streamflow (Fig. 2). The streamflow in winter, which only accounts for $4 \%$ of the annual streamflow (Fig. 2), is only recharged by groundwater, which is greatly affected by the freeze-thaw cycle of the frozen ground and the active layer (Liu et al., 2011).

\subsection{Data}

Daily streamflow and precipitation data at four hydrological stations (Fig. 1a) during the period from 1979 to 2013 are adopted to assess the changes in stream flow in a warming climate. The monthly meteorological data at three weather stations (Fig. 1a) are obtained from a distributed operational system for data sharing operated by the China Meteorological Data Service Center (http://data.cma.cn/, last access: 20 March 2019) for the years from 1979 to 2013. In this study, the meteorological data extrapolation method from Prasch et al. (2013) is adopted to obtain the discretized air temperature (with a cell size of $1 \mathrm{~km} \times 1 \mathrm{~km}$ ) of the Lhasa River basin, based on the air temperature of the three stations and assuming a linear lapse rate. The mean monthly lapse rate is set to $0.44^{\circ} \mathrm{C} 100 \mathrm{~m}^{-1}$ for elevations below $4965 \mathrm{~m}$ and $0.78^{\circ} \mathrm{C} 100 \mathrm{~m}^{-1}$ for elevations above $4965 \mathrm{~m}$ in the catchment (Wang et al., 2015).

The glacier and frozen ground data are provided by the Cold and Arid Regions Science Data Center (http://westdc. westgis.ac.cn/, last access: 15 May 2019). The distribution, area and volume of glaciers are based on the First and Second Chinese Glacier Inventory in 1960 and 2009, respectively (Mi et al., 2002; Liu et al., 2014; Fig. 1b). The distribution and classification of frozen ground (Fig. 1c) are collected from the Second Chinese Glacier Inventory maps of frozen ground on the TP (Li and Cheng, 1996; Zou et al., 2017).

The latest Level-3 monthly mascon solutions (CSR, Save et al., 2016) were used to detect terrestrial water storage (TWS, total vertically integrated water storage) changes for the period from January 2003 to December 2015 with a spatial sampling resolution of $0.5^{\circ} \times 0.5^{\circ}$ from the Gravity Recovery and Climate Experiment (GRACE) satellite. The time series from 2003 to 2015 for the snow water equivalent (SWE) and total soil moisture (SM, layer 0-200 cm) from the GLDAS_Noah2.1 dataset (https://disc.gsfc.nasa. gov/, last access: 16 May 2019) were adopted for derivation of the groundwater storage (GWS; Richey et al., 2015).

\subsection{Methods}

\subsubsection{Statistical methods for assessing streamflow changes}

The Mann-Kendall (MK) test, which is suitable for data with non-normally distributed or nonlinear trends, is applied to detect trends in hydrometeorological time series (Mann, 1945; Kendall, 1975). To remove the serial correlation from the examined time series, a trend-free pre-whitening (TFPW) procedure is needed prior to applying the MK test (Yue et al., 2002). A more detailed description of the trend-free pre-whitening (TFPW) approach was provided by Yue et al. (2002).

Gray relational analysis aims to find the major climatic or hydrological factors that influence an objective variable (Liu 


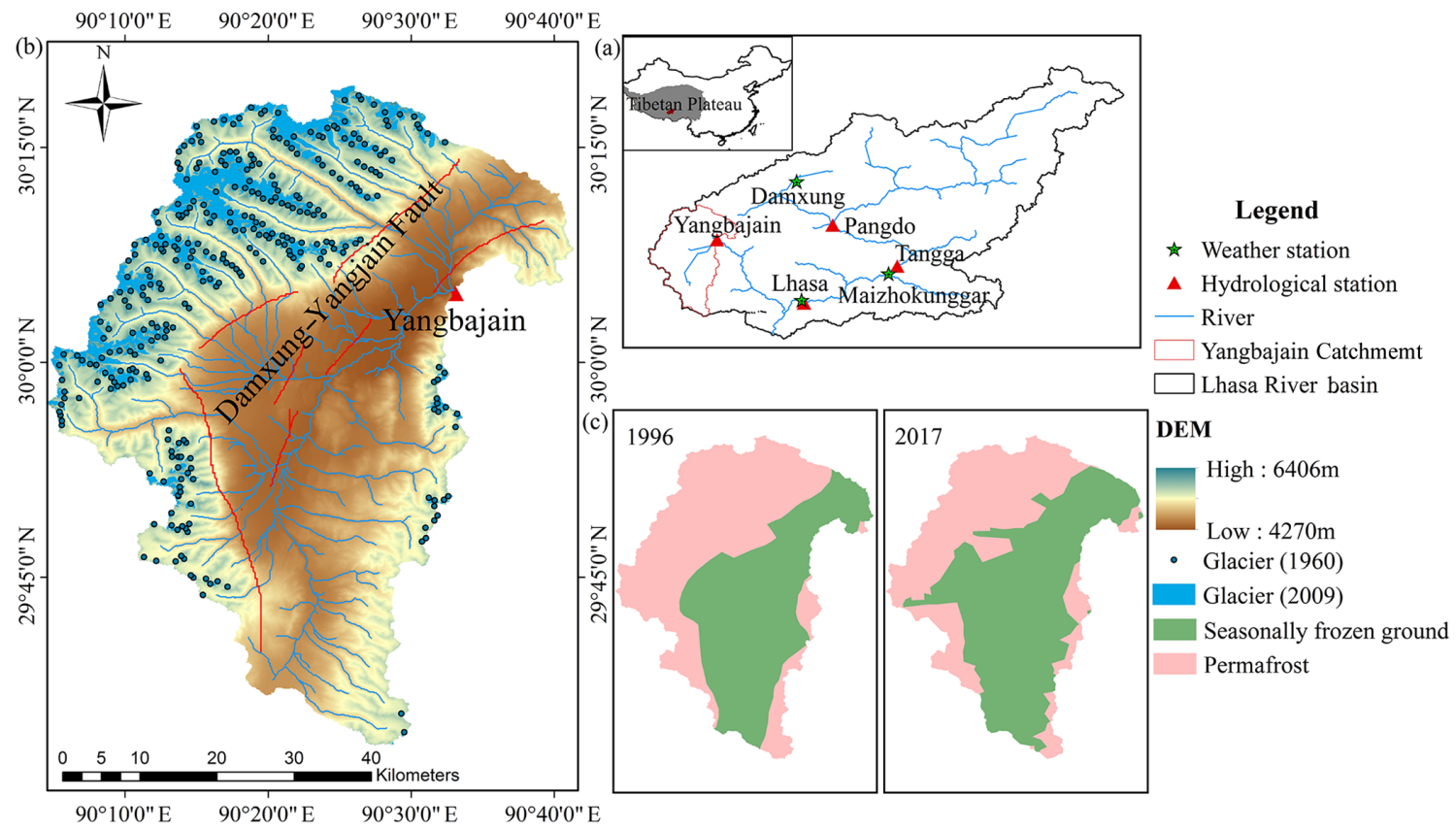

Figure 1. (a) The location, (b) elevation and glacier distribution from the Second Chinese Glacier Inventory, as only the location of glacier snouts in 1960 were provided in the First Chinese Glacier Inventory, whereas the boundaries of glaciers were shown in the Second Chinese Glacier Inventory. (c) Second Chinese Glacier Inventory maps of frozen ground distribution (Li and Cheng, 1996; Zou et al., 2017) in the Yangbajain Catchment.

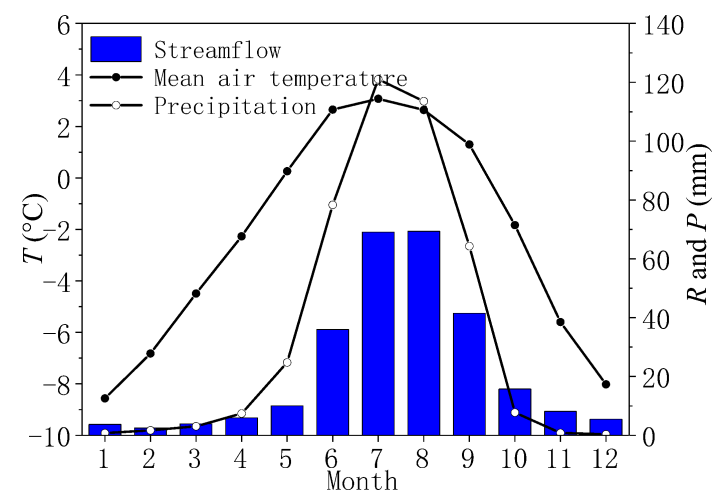

Figure 2. Seasonal variation in streamflow $(R)$, mean air temperature $(T)$ and precipitation $(P)$ in the Yangbajain Catchment.

et al., 2005; Wang et al., 2013). In this paper, gray relational analysis is used to investigate the main climatic factors impacting the streamflow changes.

\subsubsection{Baseflow separation}

In this paper, the most widely used one-parameter digital filtering algorithm is adopted for baseflow separation (Lyne and
Hollick, 1979). The filter equation is expressed as follows:

$q_{t}=\alpha q_{t-1}+\frac{1+\alpha}{2}\left(Q_{t}-Q_{t-1}\right)$

$b_{t}=Q_{t}-q_{t}$,

where $q_{t}$ and $q_{t-1}$ are the filtered quick flow at time step $t$ and $t-1$, respectively; $Q_{t}$ and $Q_{t-1}$ are the total runoff at time step $t$ and $t-1 ; \alpha$ is the filter parameter that ranging from 0.9 to 0.95 ; and $b_{t}$ is the filtered baseflow.

\subsubsection{Determination of active groundwater storage}

In this study, the active groundwater storage (abbreviated as groundwater storage in the following context) is assumed to be a storage that directly controls streamflow dynamics during rainless periods (Kirchner, 2009; Staudinger, 2017). Based on hydraulic groundwater theory, groundwater storage in a catchment can be approximated as a power function of the baseflow rate at the catchment outlet as follows (Brutsaert, 2008):

$S=K y^{m}$,

where $y$ is the rate of baseflow in the stream, and $S$ is the volume of active groundwater storage in the catchment aquifers under climate warming (see in Fig. 3). Here $K$ and $m$ are constants depending on the catchment physical characteristics; $K$ is the baseflow recession coefficient, which represents the timescale of the catchment streamflow recession process. 


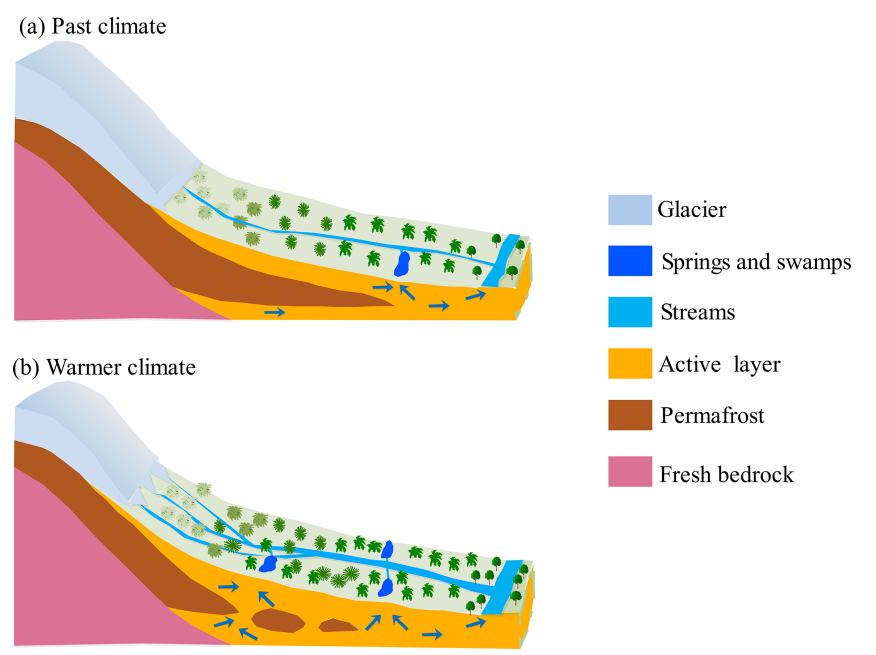

Figure 3. Diagram depicting the changes in surface water, groundwater and active groundwater storage due to glacier melt and permafrost thawing under (a) past climate and (b) a warmer climate.

During the dry season, without precipitation and other input events, the conservation of mass equation can be represented as

$$
\frac{\mathrm{d} S}{\mathrm{~d} t}=-y
$$

where $t$ is time. The substitution of Eq. (3) into Eq. (4) yields (Brutsaert and Nieber, 1977)

$$
-\frac{\mathrm{d} y}{\mathrm{~d} t}=a y^{b}
$$

where $\mathrm{d} y / \mathrm{d} t$ is the temporal change in the baseflow rate during recessions, and the constants $a$ and $b$ are the recession intercept and recession slope of the plots of $-\mathrm{d} y / \mathrm{d} t$ versus $y$ in log-log space, respectively. In the storage-discharge relationship, the aquifer responds as a linear reservoir if $b=1$, and the aquifer responds as a nonlinear reservoir if $b \neq 1$. In addition, with a fixed slope of $b$, the changes in the catchment aquifer properties due to fitting the intercept $a$ as a variable can be observed (Rupp and Selker, 2006).

According to Gao et al. (2017), the parameters of $K$ and $m$ in Eq. (3) can be expressed by $a$ and $b$, where $K=$ $1 /[a(2-b)]$ and $m=2-b$. Furthermore, the constants $a$ and $b$ can be determined via the recession slope curve technique. In this study, the two constants are curve-fitted using a nonlinear least squares regression through all of the data points of $-\mathrm{d} y / \mathrm{d} t$ versus $y$ in $\log -\log$ space for all years in order to avoid the difficulty of defining a lower envelop of the scattered points (Lyon et al., 2009). According to the values of $a$ and $b, K$ and $m$ can be calculated. Thus, the average groundwater storage $S$ for the dry season can be obtained via Eq. (3) based on the average baseflow rate.

\section{Results}

\subsection{Assessment of streamflow changes}

The annual streamflow in the Yangbajain Catchment shows an increasing trend at the $5 \%$ significance level with a mean rate of about $12.30 \mathrm{~mm}$ per decade over the period from 1979 to 2013 (Table 1, Fig. 4a). Meanwhile, the annual mean air temperature exhibits an increasing trend at the $1 \%$ significance level with a mean rate of about $0.28^{\circ} \mathrm{C}$ per decade (Table 1, Fig. 5a). However, annual precipitation has a nonsignificant trend during this period (Table 1, Fig. 5b).

As annual streamflow increases significantly, it is necessary to analyze the extent to which the changes in the two components (quick flow and baseflow) lead to streamflow increases. Based on the baseflow separation method, the annual mean baseflow contributes about $59 \%$ of the annual mean streamflow in the catchment. The MK test shows that annual baseflow exhibits a significant increasing trend at the $1 \%$ significance level with a mean rate of about $10.95 \mathrm{~mm}$ per decade over the period from 1979 to 2013 (Table 1, Fig. 4b). However the trend is statistically nonsignificant for annual quick flow during the same period (Table 1). The increasing trends between the baseflow and streamflow are very close, indicating that the increase in baseflow is the main contributor to streamflow increases.

Furthermore, gray relational analysis is applied to the catchment to identify the major climatic factors for the increasing streamflow. The result shows that the air temperature has a higher gray relational grade at the annual scale (Table 2). This indicates that the air temperature acts as a primary factor for the increased streamflow as well as the baseflow.

The annual streamflow and baseflow significantly increase due to the rising air temperature over the period from 1979 to 2013. However, there are diverse intra-annual variation characteristics for streamflow as well as the two streamflow components during the period. Streamflow in spring (March to May), fall (September to November) and winter (December to February) show increasing trends at least at the $5 \%$ significance level (Fig. 6a, c and d), while streamflow in summer (June to August) has a nonsignificant trend during this period (Fig. 6b). Baseflow also increases significantly in spring, fall and winter (Fig. 6a, c, d). The trend is statistically nonsignificant for baseflow in summer (Fig. 6b). Quick flow exhibits a nonsignificant trend for all seasons (Table 1). As for the meteorological factors, mean air temperature increases significantly at the $1 \%$ (significance) level in all seasons, especially during winter with a rate of about $0.51{ }^{\circ} \mathrm{C}$ per decade (Table 1, Fig. 7), whereas precipitation in each season shows a nonsignificant trend during these years (Table 1). The gray relational analysis shows that the air temperature is a critical climatic factor with respect to the changes in streamflow and baseflow in all seasons (Table 2). 

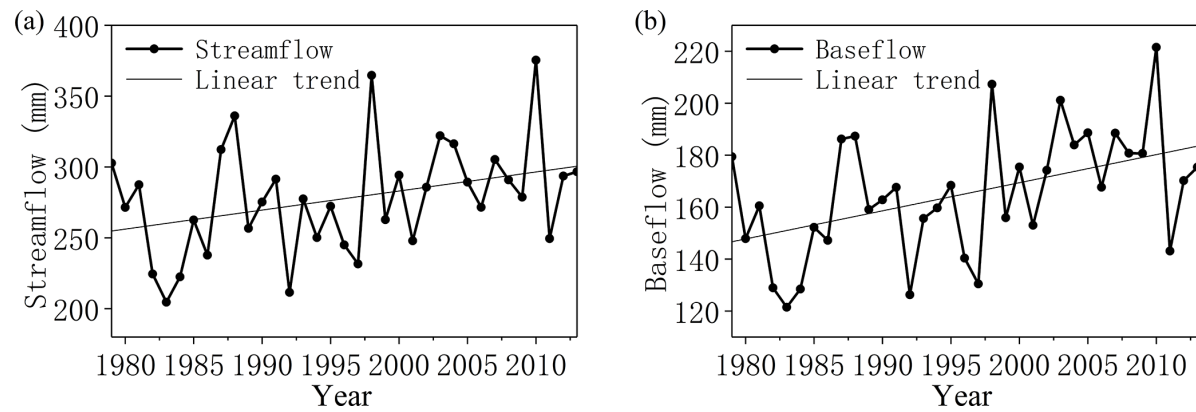

Figure 4. Variations in the annual (a) streamflow and (b) baseflow from 1979 to 2013.

Table 1. Mann-Kendall trend test with trend-free pre-whitening of seasonal and annual mean air temperature $\left({ }^{\circ} \mathrm{C}\right)$, precipitation $(\mathrm{mm})$, streamflow (mm), baseflow (mm) and quick flow (mm) from 1979 to 2013.

\begin{tabular}{lrr|rr|rr|rr|r|r|r}
\hline & \multicolumn{2}{c}{ Air temperature } & \multicolumn{2}{c|}{ Precipitation } & \multicolumn{2}{c|}{ Streamflow } & \multicolumn{2}{c}{ Baseflow } & Quick flow \\
\cline { 2 - 9 } & $Z_{C}$ & $\beta\left({ }^{\circ} \mathrm{Ca}^{-1}\right)$ & $Z_{C}$ & $\beta\left(\mathrm{mm} \mathrm{a}^{-1}\right)$ & $Z_{C}$ & $\beta\left(\mathrm{mm} \mathrm{a}^{-1}\right)$ & $Z_{C}$ & $\beta\left(\mathrm{mm} \mathrm{a}^{-1}\right)$ & $Z_{C}$ & $\beta\left(\mathrm{mm} \mathrm{a}^{-1}\right)$ \\
\hline Spring & $2.73^{* *}$ & 0.026 & 0.90 & 0.290 & $3.05^{* *}$ & 0.206 & $2.99^{* *}$ & 0.147 & 0.98 \\
Summer & $2.63^{* *}$ & 0.013 & 1.30 & 2.139 & 0.92 & 0.549 & 1.27 & 0.429 & 0.50 & 0.042 \\
Fall & $2.65^{* *}$ & 0.024 & -0.68 & -0.395 & $2.46^{*}$ & 0.546 & $2.96^{* *}$ & 0.476 & 0.80 & 0.074 \\
Winter & $3.49^{* *}$ & 0.051 & -0.46 & -0.014 & $3.08^{* *}$ & 0.204 & $2.13^{*}$ & 0.145 & 1.39 & 0.016 \\
Annual & $4.48^{* *}$ & 0.028 & 1.28 & 2.541 & $2.07^{*}$ & 1.230 & $2.70^{* *}$ & 1.095 & 0.77 & 0.327 \\
\hline
\end{tabular}

$Z_{C}$ and $\beta$ refer to the standardized test statistic and the trend magnitude, respectively; positive values of $Z_{C}$ and $\beta$ indicate an upward trend, whereas negative values indicate a downward trend in the tested time series; " "* and "**" denote statistical significance at the $5 \%$ and $1 \%$ significance levels, respectively.

\subsection{Estimation of groundwater storage by baseflow recession analysis}

Daily streamflow and precipitation records in fall and early winter (September to December) were adopted. During this dry season, the hydrograph usually shows little precipitation and declines consecutively and smoothly. The fitted slope $b$ is equal to 1.79 via the nonlinear least squares fit from Eq. (5) for all data points of $-\mathrm{d} y / \mathrm{d} t$ versus $y$ in $\log -\log$ space during the period from 1979 to 2013. Moreover, for each decade or year, the intercept $a$ could be fitted by the fixed slope $b=1.79$. The values of $K$ and $m$ for each decade or year can then be determined, and the groundwater storage $S$ for each year can be directly estimated from the average rate of baseflow during a recession period using Eq. (3).

Figure 8 shows the results of the nonlinear least squares fit for each decade's recession data from the 1980s, 1990s and 2000s, respectively. As shown in Fig. 8, the recession data points and fitted recession curves of each decade gradually move downward as time goes on. This indicates that, with a fixed slope of $b$, the intercept $a$ gradually decreases and the recession coefficient $K$ increases accordingly. The values of the recession coefficient $K$ for each decade are 77, 84 and $103 \mathrm{~mm}^{0.79} \mathrm{~d}^{0.21}$ for the $1980 \mathrm{~s}, 1990 \mathrm{~s}$ and $2000 \mathrm{~s}$, respectively. Furthermore, Fig. 9a shows the inter-annual variation in the recession coefficient $K$ during the period from 1979 to 2013. In total, although there are some large fluctuations or even a rather large decrease at the beginning of the 1990s, the overall increasing trend of $7.70\left(\mathrm{~mm}^{0.79} \mathrm{~d}^{0.21}\right)$ per decade at a significance level of $5 \%$ is similar to the results obtained from decadal analysis. This long-term variation in the recession coefficient $K$ from September to December indicates that baseflow recession gradually slows down in the catchment during fall and early winter.

According to the results of the decadal data fit (see in Fig. 8), the mean values of groundwater storage $S$ estimated for each decade are 130, 148 and $188 \mathrm{~mm}$ for the 1980s, 1990s and 2000s, respectively. The inter-annual variation in the groundwater storage $S$ is also similar to the recession coefficient $K$ (Fig. 9a, b). The decreasing trend in the anomaly changes in groundwater storage (GWS) estimated using the GRACE data is consistent with the annual trend of $S$ during the 2003-2015 period (Fig. 9b). Furthermore, the reduced volumes of groundwater between GWS and $S$ are also comparable $(\sim 100-120 \mathrm{~mm})$, which has partly verified our estimations.

The trend analysis suggests that the groundwater storage $S$ shows an increasing trend at the $5 \%$ significance level with a rate of about $19.32 \mathrm{~mm}$ per decade during the period from 1979 to 2013 (Fig. 9b). The annual trend of groundwater storage $S$ from 1979 to 2013 is consistent with the values across decades. This indicates that groundwater storage has increased. Through recent field investigations, we know that the groundwater level is rising. The increases in surface water and shallow groundwater storage are changing the land cover. For example, the normalized difference vegetation in- 
Table 2. Gray relational grades between the streamflow/baseflow and climate factors $\left(G_{\mathrm{oi}}\right.$; precipitation and air temperature) in the Yangbajain Catchment at both the annual and seasonal scales. Bold text shows the higher gray relational grade in each season.

\begin{tabular}{lrr|rr}
\hline & \multicolumn{2}{c|}{$G_{\mathrm{oi}}$ with the streamflow } & \multicolumn{2}{c}{$G_{\text {oi }}$ with the baseflow } \\
\cline { 2 - 5 } & Precipitation & Air temperature & Precipitation & Air temperature \\
\hline Spring & 0.690 & $\mathbf{0 . 7 7 8}$ & 0.713 & $\mathbf{0 . 7 8 9}$ \\
Summer & 0.689 & $\mathbf{0 . 7 8 4}$ & 0.680 & $\mathbf{0 . 7 7 6}$ \\
Fall & 0.653 & $\mathbf{0 . 6 6 7}$ & 0.648 & $\mathbf{0 . 6 8 0}$ \\
Winter & 0.742 & $\mathbf{0 . 8 8 6}$ & 0.748 & $\mathbf{0 . 8 9 5}$ \\
Annual & 0.675 & $\mathbf{0 . 7 2 7}$ & 0.665 & $\mathbf{0 . 7 2 9}$ \\
\hline
\end{tabular}

The importance of each influencing factor can be determined by the order of the gray relational grade values. The influencing factor with the largest $G_{\mathrm{oi}}$ is regarded as the main stress factor for the objective variable.
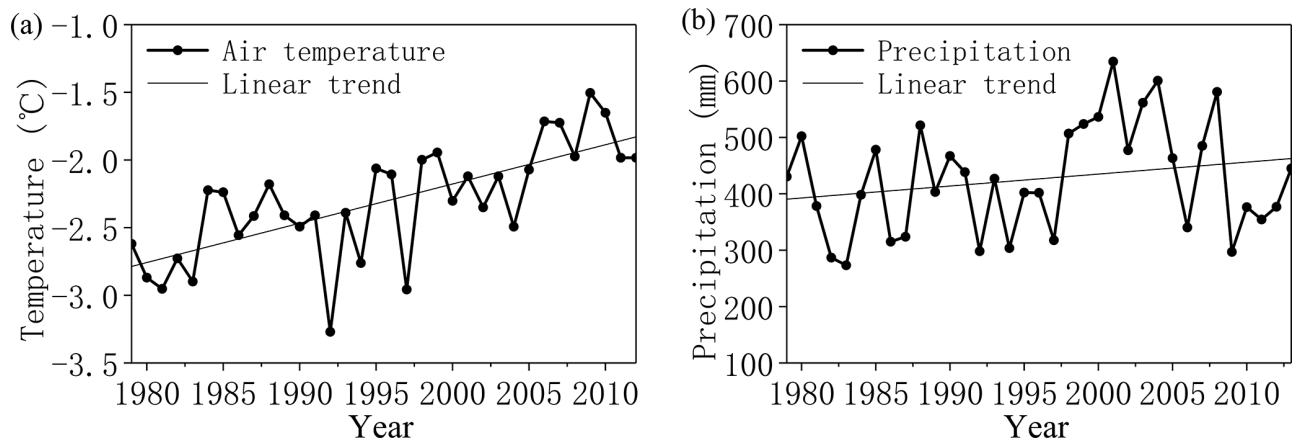

Figure 5. Variations in annual (a) mean air temperature and (b) precipitation from 1979 to 2013.

dex (NDVI) has risen accordingly over the past 20 years (Fig. 10). This rise in the NDVI (or the improvement in the vegetation conditions) stems from the fact that surface water and groundwater storage are increasing due to climate warming - not only in the study area but also across the whole TP (Zhang et al., 2018; Khadka et al., 2018).

\section{Discussion}

The results have revealed that the increase in streamflow, especially in the dry season, is tightly related to climate warming. It is obvious that both glacier retreat and frozen ground degradation in a warmer climate can significantly alter the mechanism of streamflow. In the Yangbajain Catchment as well as the whole Lhasa River basin, a noticeable glacier retreat and frozen ground degradation has been occurring over the past few decades (Table 3). For instance, according to the Second Glacier Inventory map of frozen ground distribution on the TP (Li and Cheng, 1996; Zou et al., 2017), the areal extent of permafrost in the Yangbajain Catchment has decreased by $406 \mathrm{~km}^{2}(15.3 \%)$ over the past 22 years; the areal extent of seasonal frozen ground has increased by $406 \mathrm{~km}^{2}(15.3 \%)$ with the corresponding degradation of permafrost.

According to the new map of the permafrost distribution on the TP (Zou et al., 2017), the coverage of permafrost and seasonally frozen ground in each sub-catchment (especially the Lhasa sub-catchments) are comparable to that in the Yangbajain Catchment; however, the coverage of glaciers in the three catchments is far lower than that in the Yangbajain Catchment according to the First Chinese Glacier Inventory (Mi et al., 2002; Table 3). The MK test showed that the annual mean air temperature significantly increased at the $1 \%$ significance level in all the four catchments, whereas the annual precipitation showed nonsignificant trends (Table 4). The changes in annual streamflow in the Lhasa, Pangdo and Tangga catchments showed nonsignificant trends. The reason for this was that all three larger sub-catchments as well as the whole Lhasa River basin possess relatively lower glacier coverage compared with the Yangbajain Catchment, and summer rainfall contributes $48 \%$ of the total runoff in the three larger sub-catchments and the Lhasa River basin according to Guan et al. (1984). However the annual streamflow of the Yangbajain Catchment showed an increasing trend in streamflow at the $5 \%$ significance level with a mean rate of about $12.30 \mathrm{~mm}$ per decade during the study period. Ye et al. (1999) stated that when glacier coverage is greater than $5 \%$, the glacier contribution to streamflow induced by climate warming starts to become obvious. As reported by Prasch et al. (2013), the contribution of accelerated glacial meltwater to streamflow would cause a significant increase in streamflow in the Yangbajain Catchment. Thus, it is rea- 

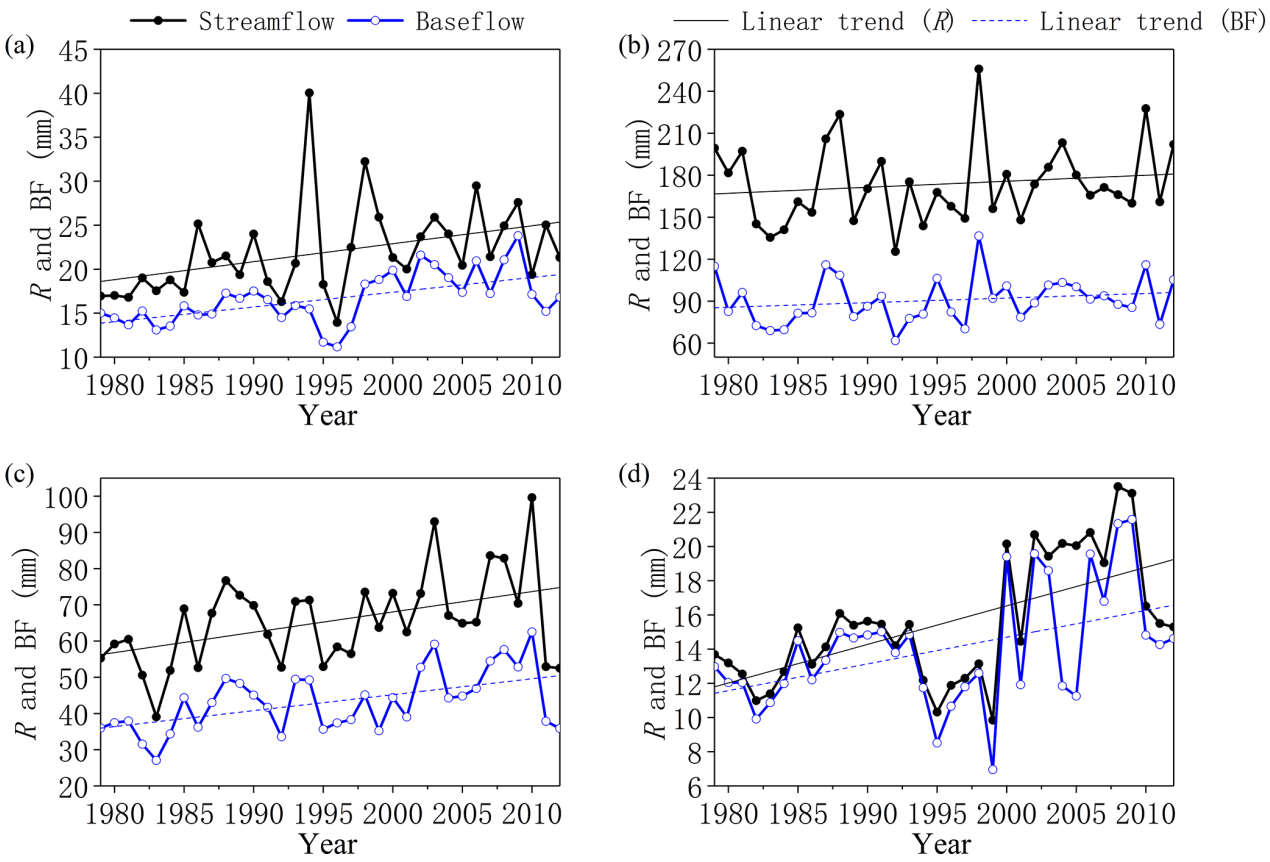

Figure 6. Variations in seasonal streamflow and baseflow in (a) spring, (b) summer, (c) fall and (d) winter from 1979 to 2013.
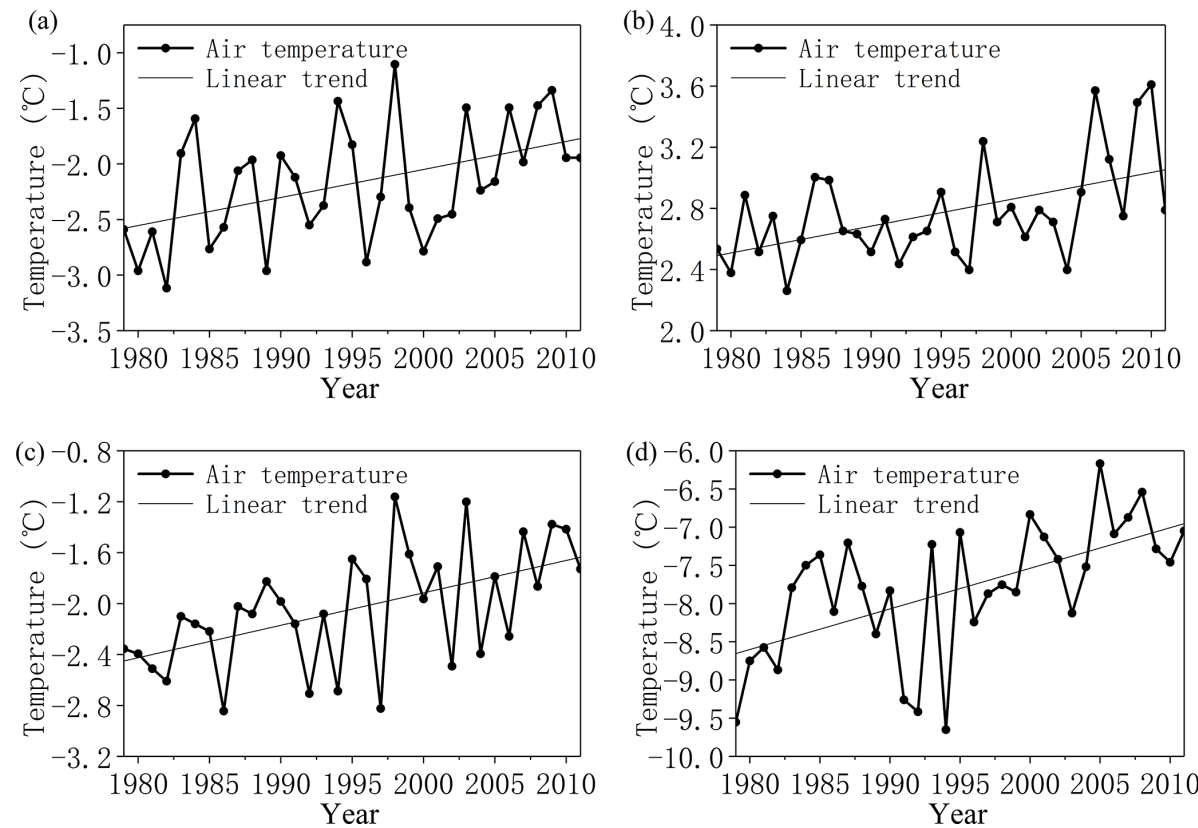

Figure 7. Variations in seasonal mean air temperature in (a) spring, (b) summer, (c) fall and (d) winter from 1979 to 2013.

sonable to attribute annual streamflow increases to the accelerated glacier retreat as a consequence of increasing annual air temperature in the Yangbajain Catchment.

Although permafrost degradation is not the controlling factor for the increase in streamflow, a rational hypothesis is that increased groundwater storage $S$ in fall and early winter is associated with frozen ground degradation, which can enlarge groundwater storage capacity (Niu et al., 2016). Figure 3 depicts the changes in surface flow and groundwater flow paths in a glacier-fed catchment, which is underlain by frozen ground under past climate and a warmer climate, respectively. As the frozen ground extent continues to decline and the active layer thickness continues to increase in the valley, the increase in the groundwater storage capacity can 
Table 3. The coverage of glaciers and frozen ground in four catchments of the Lhasa River basin.

\begin{tabular}{|c|c|c|c|c|c|c|c|c|c|c|c|c|c|}
\hline \multirow[t]{2}{*}{ Stations } & \multirow[t]{2}{*}{$\begin{array}{r}\text { Area } \\
\left(\mathrm{km}^{2}\right)\end{array}$} & \multicolumn{2}{|c|}{$\begin{array}{c}\text { Glaciers } \\
(1960)\end{array}$} & \multicolumn{2}{|c|}{$\begin{array}{l}\text { Glaciers } \\
\text { (2009) }\end{array}$} & \multicolumn{2}{|c|}{$\begin{array}{l}\text { Permafrost } \\
\text { (1996) }\end{array}$} & \multicolumn{2}{|c|}{$\begin{array}{l}\text { Permafrost } \\
\text { (2017) }\end{array}$} & \multicolumn{2}{|c|}{$\begin{array}{l}\text { Seasonally frozen } \\
\text { ground (1996) }\end{array}$} & \multicolumn{2}{|c|}{$\begin{array}{c}\text { Seasonally frozen } \\
\text { ground (2017) }\end{array}$} \\
\hline & & $\begin{array}{r}\text { Area } \\
\left(\mathrm{km}^{2}\right)\end{array}$ & $\begin{array}{r}\text { Coverage } \\
(\%)\end{array}$ & $\begin{array}{r}\text { Area } \\
\left(\mathrm{km}^{2}\right)\end{array}$ & $\begin{array}{r}\text { Coverage } \\
(\%)\end{array}$ & $\begin{array}{r}\text { Area } \\
\left(\mathrm{km}^{2}\right)\end{array}$ & $\begin{array}{r}\text { Coverage } \\
(\%)\end{array}$ & $\begin{array}{r}\text { Area } \\
\left(\mathrm{km}^{2}\right)\end{array}$ & $\begin{array}{r}\text { Coverage } \\
(\%)\end{array}$ & $\begin{array}{r}\text { Area } \\
\left(\mathrm{km}^{2}\right)\end{array}$ & $\begin{array}{r}\text { Coverage } \\
(\%)\end{array}$ & $\begin{array}{r}\text { Area } \\
\left(\mathrm{km}^{2}\right)\end{array}$ & $\begin{array}{r}\text { Coverage } \\
(\%)\end{array}$ \\
\hline Lhasa & 26233 & 349.26 & 1.3 & 347.14 & 1.3 & 10535 & 40.2 & 9783 & 37.3 & 15698 & 59.8 & 16450 & 62.7 \\
\hline Pangdo & 16425 & 345.24 & 2.1 & 339.90 & 2.1 & 8666 & 52.7 & 8242 & 50.2 & 7762 & 47.3 & 8184 & 49.8 \\
\hline Tangga & 20152 & 348.12 & 1.7 & 342.27 & 1.7 & 10081 & 50.0 & 9432 & 46.8 & 10071 & 50.0 & 10720 & 53.2 \\
\hline
\end{tabular}

Table 4. Mann-Kendall trend test with trend-free pre-whitening of annual mean air temperature $\left({ }^{\circ} \mathrm{C}\right)$, precipitation (mm) and streamflow $(\mathrm{mm})$ in four catchments of the Lhasa River basin.

\begin{tabular}{lrr|rr|rr}
\hline & \multicolumn{2}{c|}{ Air temperature } & \multicolumn{2}{c|}{ Precipitation } & \multicolumn{2}{c}{ Streamflow } \\
\cline { 2 - 7 } & $Z_{C}$ & $\beta\left({ }^{\circ} \mathrm{Ca}^{-1}\right)$ & $Z_{C}$ & $\beta\left(\mathrm{mm} \mathrm{a}^{-1}\right)$ & $Z_{C}$ & $\beta\left(\mathrm{mm} \mathrm{a}^{-1}\right)$ \\
\hline Lhasa & $6.07^{* *}$ & 0.028 & 1.16 & 1.581 & 1.09 & 1.420 \\
Pangdo & $6.19^{* *}$ & 0.026 & 0.89 & 1.435 & 0.30 & 0.223 \\
Tangga & $7.35^{* *}$ & 0.021 & 1.48 & 2.005 & -0.62 & -0.531 \\
Yangbajain & $4.48^{* *}$ & 0.028 & 1.28 & 2.541 & $2.07^{*}$ & 1.230 \\
\hline
\end{tabular}

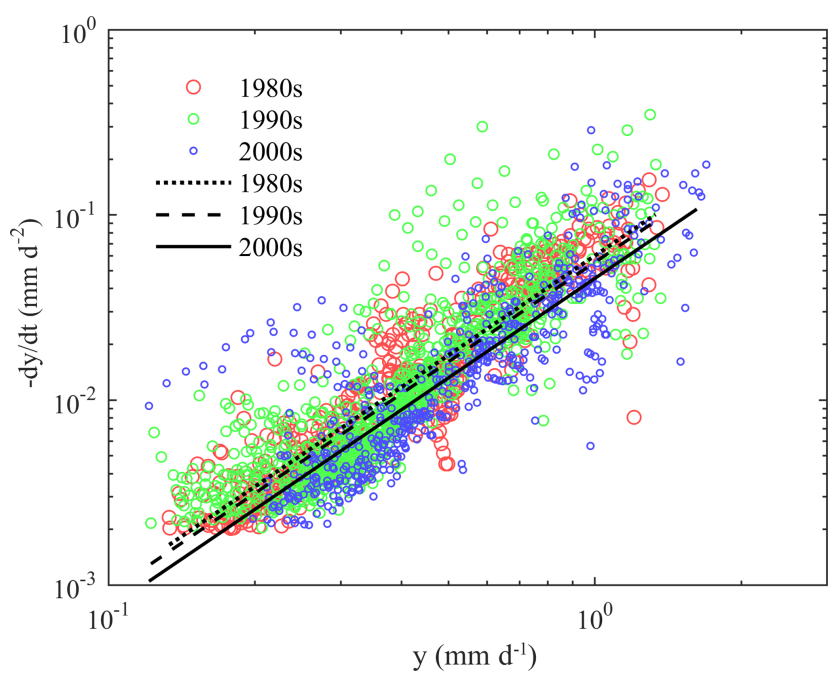

Figure 8. Recession data points of $-\mathrm{d} y / \mathrm{d} t$ versus $y$ as well as the fitted recession curves by decade in log-log space. The black dotted line, the dashed line and the solid line represent the recession curves in the 1980s, 1990s and 2000s, respectively.

provide enough storage space to accommodate the increasing meltwater that may percolate into deeper aquifers (Fig. 3). The increase in groundwater storage in fall and early winter then allows more groundwater discharge into streams as baseflow and lengthens the recession time, as indicated by the recession coefficient $K$. This leads to the increased baseflow and slow baseflow recession in fall and early winter, as is shown in Figs. 6c, d and 9a. In the late winter and spring, the increase in baseflow (Fig. 6d, a) can be explained by the delayed release of increased groundwater storage.
Thus, as a result of climate warming, the river regime in this catchment has been altered significantly. On the one hand, permafrost degradation is changing the aquifer structure that controls the storage-discharge mechanism, e.g. the catchment groundwater storage increases at about $19.32 \mathrm{~mm}$ per decade; on the other hand, a huge amount of water from glacier retreat is contributing to the increase in streamflow and groundwater storage. For example, the annual streamflow of the Yangbajain Catchment has been increasing a mean rate of about $12.30 \mathrm{~mm}$ per decade over the past 50 years. However, the total glacial area and volume have decreased by $38.05 \mathrm{~km}^{2}(12.0 \%)$ and $1788 \mathrm{~mm}(26.2 \%)$, respectively, over the period from 1960 to 2009 (Fig. 11) according to the Chinese glacier inventories. Hence, the glacial volume reduction rate has been $9.46 \times 10^{7} \mathrm{~m}^{3} \mathrm{a}^{-1}$ (about $357.7 \mathrm{~mm}$ per decade) on average over the past 50 years. With respect to the ablation on continental-type glaciers in China, evaporation (sublimation) always plays an important role; however, the annual amount of evaporation is usually less than $30 \%$ of the total ablation of glaciers in the high mountains of China (Zhang et al., 1996). Given the $30 \%$ reduction in glacial melt, there is still a large water imbalance between the melt-derived runoff and the actual increase in runoff and groundwater storage. Our results imply that more than $60 \%$ of glacial meltwater would be lost by subsurface leakage.

\section{Conclusions}

In this study, changes in hydrometeorological variables were evaluated in order to identify the main climatic factor for 

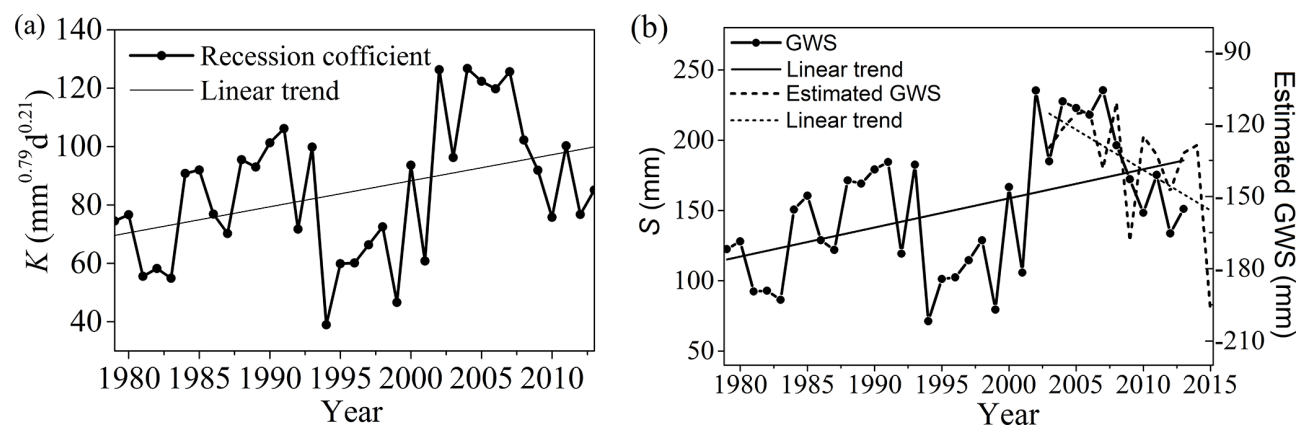

Figure 9. Variations in (a) the recession coefficient $K$ and (b) the estimated groundwater storage $S$ from 1979 to 2013 as well as the estimated groundwater storage changes from 2003 to 2015 from GRACE data.

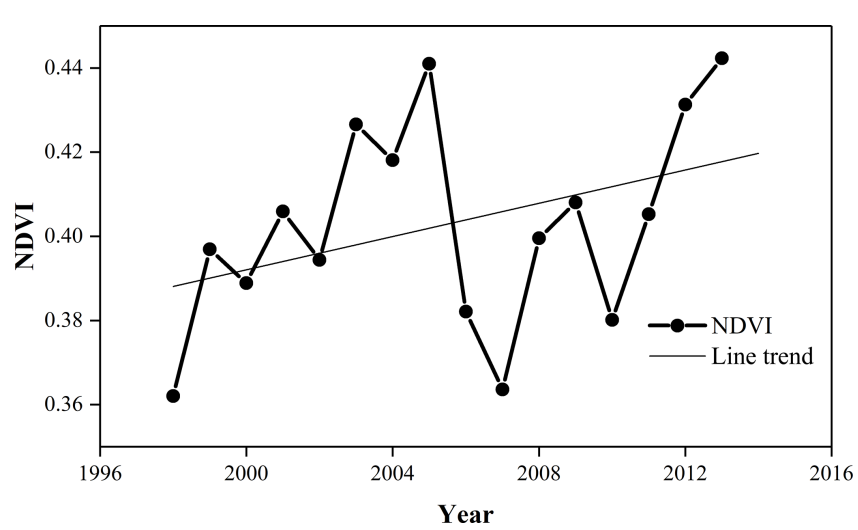

Figure 10. Variations in the annual NDVI from 1998 to 2013 in the catchment.

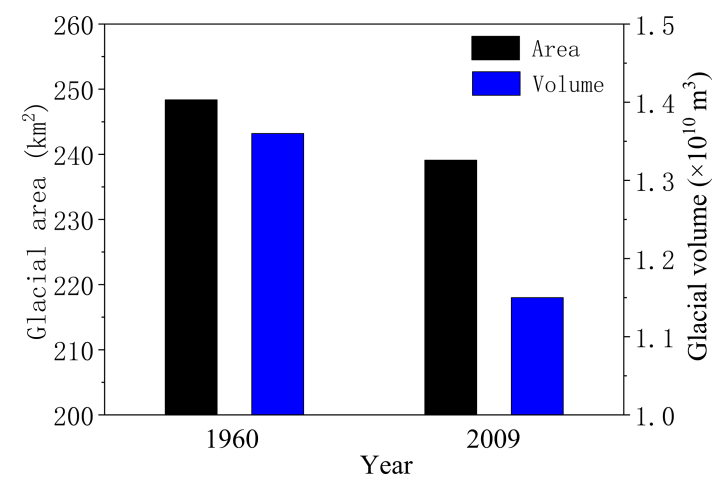

Figure 11. The total area and volume of glaciers in the Yangbajain Catchment in 1960 and 2009.

streamflow changes in the cryospheric Yangbajain Catchment. We find that the annual streamflow, especially the annual baseflow, increases significantly, and the rising air temperature acts as a primary factor for the increased runoff. Furthermore, through parallel comparisons of subbasins in the Lhasa River basin, we presume that the increased streamflow in the Yangbajain Catchment is mainly fed by glacier retreat. Due to climate warming, the total glacial area and volume have decreased by $38.05 \mathrm{~km}^{2}(12.0 \%)$ and $4.73 \times 10^{9} \mathrm{~m}^{3}$ $(26.2 \%)$, respectively between 1960 and 2009 , and the areal extent of permafrost has degraded by $406 \mathrm{~km}^{2}(15.3 \%)$ over the past 22 years. As a result of permafrost degradation, the groundwater storage capacity has increased, which has triggered a continuous increase in groundwater storage at a rate of about $19.32 \mathrm{~mm}$ per decade. This can explain why the baseflow volume increases and baseflow recession slows down in fall and early winter.

Finally, we find that there is a large water imbalance $\left(>5.79 \times 10^{7} \mathrm{~m}^{3} \mathrm{a}^{-1}\right)$ between the melt-derived runoff and the actual increase in runoff and groundwater storage, which suggests that more than $60 \%$ of the reduction in glacial melt should be lost by subsurface leakage. However, the pathway of these leakage is still an open question that requires further study. More methods (e.g. hydrological isotopes) should be adopted to quantify the contribution of glacial meltwater and permafrost degradation to streamflow as well as to explore the change in groundwater storage capacity as frozen ground continues to degrade.

Code and data availability. The code and data used in this study are available from Jintao Liu (jtliu@ @hu.edu.cn) upon request.

Author contributions. LL and JL provided insights; LL and MG performed the coding and analysis; LL drafted the paper with contributions from all co-authors. JL and XC collected the data. JL, JW, SW and HL contributed to the analysis of the results, the discussion and edited the paper.

Competing interests. The authors declare that they have no conflict of interest.

Acknowledgements. We would like to thank the editor, Fuqiang Tian, and the two anonymous reviewers, whose perceptive criticisms, comments and suggestions helped us improve the quality of the paper. 
Financial support. This work was supported by the Second Tibetan Plateau Scientific Expedition and Research Program (STEP; Ministry of science and technology, MOST; grant no. 2019QZKK0207), the National Natural Science Foundation of China (NSFC; grant nos. 91647108 and 91747203), the Science and Technology Program of Tibet Autonomous Region (grant no. 2015XZ01432), the West Light Foundation of the Chinese Academy of Sciences (grant no. 29Y929621) and the Special Fund of the State Key Laboratory of Hydrology-Water Resources and Hydraulic Engineering (grant no. 20185044312).

Review statement. This paper was edited by Fuqiang Tian and reviewed by two anonymous referees.

\section{References}

Bense, V. F., Kooi, H., Ferguson, G., and Read, T.: Permafrost degradation as a control on hydrogeological regime shifts in a warming climate, J. Geophys. Res.-Earth, 117, F03036, https://doi.org/10.1029/2011JF002143, 2012.

Bibi, S., Wang, L., Li, X. P., Zhou, J., Chen, D. L., and Yao, T. D.: Climatic and associated cryospheric, biospheric, and hydrological changes on the Tibetan Plateau: A review, Int. J. Climatol., 38, e1-e17, https://doi.org/10.1002/joc.5411, 2018.

Brutsaert, W.: Long-term groundwater storage trends estimated from streamflow records: Climatic perspective, Water Resour. Res., 44, 114-125, https://doi.org/10.1029/2007WR006518, 2008.

Brutsaert, W. and Nieber, J. L.: Regionalized drought flow hydrographs from a mature glaciated plateau, Water Resour. Res., 13, 637-643, 1977.

Buttle, J. M.: Mediating stream baseflow response to climate change: the role of basin storage, Hydrol. Process., 32, 363-378, https://doi.org/10.1002/hyp.11418, 2017.

Chapman, T.: A comparison of algorithms for stream flow recession and baseflow separation, Hydrol. Process., 13, 701-714, 1999.

Cheng, G. D. and Wu, T. H.: Responses of permafrost to climate change and their environmental significance, Qinghai-Tibet Plateau, J. Geophys. Res.-Earth, 112, F02S03, https://doi.org/10.1029/2006JF000631, 2007.

Cuo, L., Zhang, Y. X., Zhu, F. X., and Liang, L. Q.: Characteristics and changes of streamflow on the Tibetan Plateau: A review, J. Hydrol., 2, 49-68, https://doi.org/10.1016/j.ejrh.2014.08.004, 2014.

Duan, L., Man, X., Kurylyk, B. L., and Cai, T.: Increasing winter baseflow in response to permafrost thaw and precipitation regime shifts in northeastern China, Water, 9, 25, https://doi.org/10.3390/w9010025, 2017.

Gao, M., Chen, X., Liu, J., Zhang, Z., and Cheng, Q.: Using two parallel linear reservoirs to express multiple relations of power-law recession curves, J. Hydrol. Eng., 22, 04017013, https://doi.org/10.1061/(ASCE)HE.1943-5584.0001518, 2017.

Ge, S., McKenzie, J., Voss, C., and Wu, Q.: Exchange of groundwater and surface-water mediated by permafrost response to seasonal and long term air temperature variation, Geophys. Res. Lett., 38, L14402, https://doi.org/10.1029/2011GL047911, 2011.
Guan, Z. H., Chen, C. Y., Kuang, Y. X., Fan Y. Q., Zhang, Y. S., Chen, Z. M., Bao, S. H., Zu, Y. T., He, X. W., and Zhang, M. T.: Rivers and Lakes in Tibetan, Science and Technology Press, Beijing, 1984 (in Chinese).

Green, T. R., Taniguchi, M., Kooi, H., Gurdak, J. J., Allen, D. M., Hiscock, K. M., Treidel, H., and Aureli, A.: Beneath the surface of global change: impacts of climate change on groundwater, J. Hydrol., 405, 532-560, https://doi.org/10.1016/j.jhydrol.2011.05.002, 2011.

Immerzeel, W. W., van Beek, L. P. H., and Bierkens, M. F. P.: Climate change will affect the Asian water towers, Science, 328 , 1382-1385, 2010.

Jiang, W., Han, Z., Zhang, J., and Jiao, Q.: Stream profile analysis, tectonic geomorphology and neotectonic activity of the Damxung-Yangbajain Rift in the south Tibetan Plateau, Earth Surf. Proc. Land., 41, 1312-1326, https://doi.org/10.1002/esp.3899, 2016.

Kang, S. C., Xu, Y. W., You, Q. L., Flügel, W. A., Pepin, N., and Yao, T. D.: Review of climate and cryospheric change in the Tibetan Plateau, Environ. Res. Lett., 5, 015101, https://doi.org/10.1088/1748-9326/5/1/015101, 2010.

Käser, D. and Hunkeler, D.: Contribution of alluvial groundwater to the outflow of mountainous catchments, Water Resour. Res., 52, 680-697, https://doi.org/10.1002/2014WR016730, 2016.

Kendall, M. G.: Rank Correlation Methods, 4th ed., Charles Griffin, London, 196 pp., 1975.

Khadka, N., Zhang, G., and Thakuri, S.: Glacial Lakes in the Nepal Himalaya: Inventory and Decadal Dynamics (1977-2017), Remote Sensing, 10, 1913, https://doi.org/10.3390/rs10121913, 2018.

Kirchner, J. W.: Catchments as simple dynamical systems: catchment characterization, rainfall-runoff modeling, and doing hydrology backward, Water Resour. Res., 45, W02429, https://doi.org/10.1029/2008WR006912, 2009.

Kooi, H., Ferguson, G., and Bense, V. F.: Evolution of shallow groundwater flow systems in areas of degrading permafrost, Geophys. Res. Lett., 36, 297-304, 2009.

Li, S. and Cheng, G.: Map of Frozen Ground on Qinghai-Xizang Plateau, Gansu Culture Press, Lanzhou, 1996.

Li, Z. J., Li, Z. X., Song, L. L., Ma, J. Z., and Song Y.: Environment significance and hydrochemical characteristics of suprapermafrost water in the source region of the Yangtze River, Sci. Total Environ., 644, 1141-1151, 2018.

Lin, K. T. and Yeh, H. F.: Baseflow recession characterization and groundwater storage trends in northern Taiwan, Hydrol. Res., 48, 1745-1756, 2017.

Liu, J. S., Xie, J., Gong, T. L., Wang, D., and Xie, Y. H.: Impacts of winter warming and permafrost degradation on water variability, upper Lhasa River, Tibet, Quatern. Int., 244, 178-184, https://doi.org/10.1016/j.quaint.2010.12.018, 2011.

Liu, J. T., Han, X. L., Chen, X., Lin, H., and Wang, A. H.: How well can the subsurface storage-discharge relation be interpreted and predicted using the geometric factors in headwater areas?, Hydrol. Process., 30, 4826-4840, https://doi.org/10.1002/hyp.10958, 2016.

Liu, Q. Q, Singh, V. P., and Xiang, H.: Plot erosion model using gray relational analysis method, J. Hydrol. Eng., 10, 288-294, 2005. 
Liu, S. Y., Guo, W., Xu, J. L., Wu, L. Z., Yao, X. J., Wei, J. F., and Shangguan, D. Y.: The Second Glacier Inventory Dataset of China (Version 1.0), Cold and Arid Regions Science Data Center at Lanzhou, https://doi.org/10.3972/glacier.001.2013.db, 2014.

Liu, X. D. and Chen, B. D.: Climatic warming in the Tibetan Plateau during recent decades, Int. J. Climatol., 20, 1729-1742, 2000.

Lyne, V. and Hollick, M.: Stochastic time-variable rainfall-runoff modeling, Aust. Natl. Conf. Publ., 89-93, 1979.

Lyon, S. W. and Destouni, G.: Changes in catchment-scale recession flow properties in response to permafrost thawing in the Yukon River basin, Int. J. Climatol., 30, 2138-2145, https://doi.org/10.1002/joc.1993, 2010.

Lyon, S. W., Destouni, G., Giesler, R., Humborg, C., Mörth, M., Seibert, J., Karlsson, J., and Troch, P. A.: Estimation of permafrost thawing rates in a sub-arctic catchment using recession flow analysis, Hydrol. Earth Syst. Sci., 13, 595-604, https://doi.org/10.5194/hess-13-595-2009, 2009.

Mann, H.: Non-parametric test against trend, Econometrica, 13, 245-259, 1945.

Mi, D. S., Xie, Z. C., and Luo, X. R.: Glacier Inventory of China (volume XI: Ganga River drainage basin and volume XII: Indus River drainage basin). Xi' an Cartographic Publishing House, Xi' an, 292-317, 2002 (in Chinese).

Niu, L., Ye, B. S., Li, J., and Sheng, Y.: Effect of permafrost degradation on hydrological processes in typical basins with various permafrost coverage in western China, Sci. China Earth Sci., 54, 615-624, https://doi.org/10.1007/s11430-010-4073-1, 2011.

Niu, L., Ye, B., Ding, Y., Li, J., Zhang, Y., Sheng, Y., and Yue, G.: Response of hydrological processes to permafrost degradation from 1980 to 2009 in the upper Yellow River basin, China, Hydrol. Res., 47, 1014-1024, https://doi.org/10.2166/nh.2016.096, 2016.

Patnaik, S., Biswal, B., Kumar, D. N., and Sivakumar, B.: Regional variation of recession flow power-law exponent, Hydrol. Process., 32, 866-872, 2018.

Prasch, M., Mauser, W., and Weber, M.: Quantifying present and future glacier melt-water contribution to runoff in a central Himalayan river basin, The Cryosphere, 7, 889-904, https://doi.org/10.5194/tc-7-889-2013, 2013.

Pritchard, H. D.: Asia's glaciers are a regionally important buffer against drought, Nature, 545, 169-174, https://doi.org/10.1038/nature22062, 2017.

Richey, A. S., Thomas, B. F., Lo, M.-H., Reager, J. T., Famiglietti, J. S., Voss, K., Swenson, S., and Rodell, M.: Quantifying renewable groundwater stress with GRACE, Water Resour. Res., 51, 52175238, https://doi.org/10.1002/2015WR017349, 2015.

Rogger, M., Chirico, G. B., Hausmann, H., Krainer, K., Brückl, E. , Stadler, P., and Blöschl, G.: Impact of mountain permafrost on flow path and runoff response in a high alpine catchment, Water Resour. Res., 53, 1288-1308, https://doi.org/10.1002/2016WR019341, 2017.

Rupp, D. E. and Selker, J. S.: Information, artifacts, and noise in $\mathrm{d} Q / \mathrm{d} t-Q$ recession analysis, Adv. Water Resour., 29, 154-160, 2006.

Save, H., Bettadpur, S., and Tapley, B. D.: High-resolution CSR GRACE RL05 masons, J. Geophys. Res.-Sol. Ea., 121, 75477569, doi.org/10.1002/2016JB013007, 2016.

Staudinger, M., Stoelzle, M., Seeger, S., Seibert, J., Weiler, M., and Stahl, K.: Catchment water storage varia- tion with elevation, Hydrol. Process., 31, 2000-2015, https://doi.org/10.1002/hyp.11158, 2017.

Su, F., Zhang, L., Ou, T., Chen, D., Yao, T., Tong, K., and Qi, Y.: Hydrological response to future climate changes for the major upstream river basins in the Tibetan Plateau, Global Planet. Change, 136, 82-95, https://doi.org/10.1016/j.gloplacha.2015.10.012, 2016.

Viviroli, D., Dürr, H. H., Messerli, B., Meybeck, M., and Weingartner, R.: Mountains of the world, water towers for humanity: Typology, mapping, and global significance, Water Resour. Res., 43, W07447, https://doi.org/10.1029/2006WR005653, 2007.

Walvoord, M. A. and Kurylyk, B. L.: Hydrologic impacts of thawing permafrost - A review, Vadose Zone J., 15, 1-20, https://doi.org/10.2136/vzj2016.01.0010, 2016.

Walvoord, M. A. and Striegl, R. G.: Increased groundwater to stream discharge from permafrost thawing in the Yukon River basin: Potential impacts on lateral export of carbon and nitrogen, Geophys. Res. Lett., 34, 123-134, https://doi.org/10.1029/2007GL030216, 2007.

Wang, G., Mao, T., Chang, J., Song, C., and Huang, K.: Processes of runoff generation operating during the spring and autumn seasons in a permafrost catchment on semi-arid plateaus, J. Hydrol., 550, 307-317, 2017.

Wang, S., Liu, S. X., Mo, X. G., Peng, B., Qiu, J. X., Li, M. X., Liu, C. M., Wang, Z. G., and Bauer-Gottwein, P.: Evaluation of remotely sensed precipitation and its performance for streamflow simulations in basins of the southeast Tibetan Plateau, J. Hydrometeorol., 16, 342-354, https://doi.org/10.1175/JHM-D-140166.1, 2015.

Wang, W. F., Wu, T. H., Zhao, L., Li R., Zhu X. F., Wang, W. R., Yang, S. H., Qin, Y. H., and Hao, J. M.: Exploring the ground ice recharge near permafrost table on the central Qinghai-Tibet Plateau using chemical and isotopic data, J. Hydrol., 560, 220229, 2018.

Wang, Y. F., Shen, Y. J., Chen, Y. N., and Guo, Y.: Vegetation dynamics and their response to hydroclimatic factors in the Tarim River Basin, China, Ecohydrology, 6, 927-936, 2013.

Wang, Y. H., Yang, H. B., Gao, B., Wang, T. H., Qin, Y., and Yang, D. W.: Frozen ground degradation may reduce future runoff in the headwaters of an inland river on the northeastern Tibetan Plateau, J. Hydrol., 564, 1153-1164, 2018.

Wittenberg, H.: Baseflow recession and recharge as nonlinear storage processes, Hydrol. Process., 13, 715-726, 1999.

Woo, M. K., Kane, D. L., Carey, S. K., and Yang, D.: Progress in permafrost hydrology in the new millennium, Permafrost Periglac., 19, 237-254, https://doi.org/10.1002/ppp.613, 2008.

$\mathrm{Wu}, \mathrm{Q}$. B. and Zhang, T. J.: Recent permafrost warming on the Qinghai-Tibetan Plateau, J. Geophys. Res.-Atmos., 113, D13108, https://doi.org/10.1029/2007JD009539, 2008.

$\mathrm{Wu}, \mathrm{Z}$. H. and Zhao, X. T.: Quaternary geology and faulting in the Damxung-Yangbajain Basin, southern Tibet, Journal of Geomechanics, 12, 305-316, 2006 (in Chinese).

$\mathrm{Xu}$, M., Kang, S., Wang, X., Pepin, N., and Wu H.: Understanding changes in the water budget driven by climate change in cryospheric-dominated watershed of the northeast Tibetan Plateau, China, Hydrol. Process., 33, 1040-1058, https://doi.org/10.1002/hyp.13383, 2019.

Yang, G., Lei, D., Hu, Q., Cai, Y., and Wu, J.: Cumulative coulomb stress changes in the basin-range region of Gulu-Damxung- 
Yangbajain and their effects on strong earthquakes, Electronic Journal of Geotechnical Engineering, 22, 1523-1530, 2017.

Yao, T. D., Wang, Y. Q., Liu, S. Y., Pu, J. C., Shen, Y. P., and Lu, A. $\mathrm{X}$. : Recent glacial retreat in high Asia in China and its impact on water resource in northwest China, Science in China, 47, 10651075, https://doi.org/10.1360/03yd0256, 2004.

Yao, T. D., Pu, J. C., Lu, A. X., Wang, Y. Q., and Yu, W. S.: Recent glacial retreat and its impact on hydrological processes on the Tibetan Plateau, China, and surrounding regions, Arct. Antarct. Alpine Res., 39, 642-650, 2007.

Ye, B. S., Han, T. D., and Ding, Y. J.: Some Changing Characteristics of Glacier Streamflow in Northwest China, J. Glaciol. Geocryology, 21, 54-58, 1999 (in Chinese).

Yue, S., Pilon, P., Phinney, B., and Cavadias, G.: The influence of autocorrelation on the ability to detect trend in hydrological series, Hydrol. Process., 16, 1807-1829, https://doi.org/10.1002/hyp.1095, 2002.

Zhang, Y., Yao, T. D., and Pu, J. C.: The characteristics of ablation on continental-type glaciers in China, Journal of Glaciology and Geocryology, 18, 147-154, 1996 (in Chinese).
Zhang, Y. L., Wang, C. L., Bai, W. Q., Wang, Z. F., Tu, Y. L., and Yangjaen, D. G.: Alpine wetland in the Lhasa River Basin, China, J. Geogr. Sci., 20, 375-388, 2010 (in Chinese).

Zhang, Z. X., Chang, J., Xu, C. Y., Zhou, Y., Wu, Y. H., Chen, X., Jiang, S. S., and Duan, Z.: The response of lake area and vegetation cover variations to climate change over the Qinghai-Tibetan Plateau during the past 30 years, Sci. Total Environ., 635, 443451, 2018.

Zhou, Y. W., Guo, D. X., Qiu, G. Q., Cheng, G. D., and Li, S. D.: Permafrost in China, Science Press, Beijing, 63-70, 2000 (in Chinese).

Zou, D., Zhao, L., Sheng, Y., Chen, J., Hu, G., Wu, T., Wu, J., Xie, C., Wu, X., Pang, Q., Wang, W., Du, E., Li, W., Liu, G., Li, J., Qin, Y., Qiao, Y., Wang, Z., Shi, J., and Cheng, G.: A new map of permafrost distribution on the Tibetan Plateau, The Cryosphere, 11, 2527-2542, https://doi.org/10.5194/tc-11-2527-2017, 2017. 